\title{
Ruy Duarte de Carvalho: Os dezassete nós temáticos da vida
}

\author{
Ana Paula Tavares \\ Escritora \\ estre que tem a faculdade de agir através de dezassete pontas de cordel \\ Cada qual com sete pontas e um tendão humano atado em três sitios \\ Quando eu fizer pressão sobre o nó direito \\ Abre o lugar onde o passado se enrola para que o cadáver \\ Na cova \\ Me revele o já cumprido \\ E quando pressionar o nó da esquerda \\ Abre o lugar do devir \\ Para que o que vai nascer me prediga futuros. \\ E quando for do meio \\ Entra em mim e faz-me entrar em ti: \\ Que o véu tombe \\ Que a obscuridade se dissipe \\ Que en veja as formas, oiça os sons, discirna a palavra
}

Eis que um grito atravessa os lugares habitados!

É um grito de socorro. O bem me obriga a ir ver!

Sacrificador que sou expulsarei o mal

Eis o som e eis a cinza. Deles me servirei

Para esfregar o corpo do doente

Aprovai a minha encantação:

$$
\begin{aligned}
& \text { A pazé a paz } \\
& \text { Soberana é a guerra }
\end{aligned}
$$

Ondula Savana Branca, UEA, 1989:82 
uando se lavra a jipe um país de muitos lestes e um só sul, a palavra encantada de Ruy Duarte, nosso mestre, surge para ajudar a inscrever sobre o chão batido uma rota de seda, onde se rasga a pedra, lapida a palavra e se inaugura o percurso de uma solidão aflita. A razão de Angola, "descoberta aí pelos doze anos junto ao pico do Azevedo", iria levá-lo ao caminho encantado de procurar a palavra, primeiro voz, sobretudo a voz (aquela duplicação da memória que rasga os dias e as noites), depois a escrita - a descoberta de que Angola era mais do que uma questão geográfica e que havia ali uma alma de que serenamente tomou posse e se obrigou a ensinar aos outros. O novo nascimento está para sempre ligado ao exercício da profissão de regente agrícola e a percursos entre a Catumbela (um centro nervoso com a memória do tráfico de escravos inscrita, o comércio escorrente de mel, marfim e especiarias), a criação de ovelhas e as histórias sobre tesouros perdidos, papéis e sangue, e Calulo onde a pele ganha camadas e a aflição se inscreve e transborda para a poesia (Sete cadernos entre 1972 e 1987). Entre aforismos e provérbios encontra o tom (são as vozes, sobretudo as vozes de uma oralidade com a patine do tempo) e todos os nós temáticos para escrever poesia para lá da língua "para revelar abertamente uma incidência da própria linguagem, da Cultura, da organização do discurso, da maneira de comunicar, da memória local, de uma particular visão do mundo" (e uso as próprias palavras, tantas vezes ditas outras vezes transcritas em $A$ câmara, a escrita e a coisa dita (p. 49, 50).

$\mathrm{O}$ cinema e uma nova interrogação sobre os outros para saber o que pensam de si próprios do seu lugar do mundo e do próprio mundo quando se movem diante das câmaras. Contra o filme etnográfico constrói o seu discurso que afina nos problemas e interrogações que tenta resolver para os outros e para si próprio. Pela articulação do cinema e texto frequenta a academia, os senhores doutores, uma nova pele, um ritual de passagem. Ganham os angolanos Ana manda, os filhos da rede onde muitas teorias se tornam conformes à sua áspera lucidez. Não lê nessa altura os colegas (James Clifford ou Spivak ou Homi Bhabha (eu até tenho medo de os ler Paulinha) que todo o mundo havia de incensar e citar, pois o Ruy, como disse Miguel Vale de Almeida, praticou uma antropologia pós-colonial e pós-moderna, sem se reclamar da escola, sem pagar tributo a ninguém o que lhe permitia ser mais livre e acutilante na sua Hermenêutica da Escassez, na sua escrita para lá dos géneros que tanto perturba a nossa bem comportada filiação a escolas, pensamentos, modas e momentos. 
"Angola é grande, vasta, diversa, múltipla e complexa no que diz respeito a formações sociais", afirma Ruy Duarte enquanto reúne um "dicionário do arrepio", cujas entradas se situam entre a observação e a acção, os exercícios de cidadania e a análise (texto de 1995). O efeito multiplicador encontra-se na variedade dos textos e na assunção de um papel de actor social, interveniente, directo: angolano, poeta, homem da ciência. Observação directa é o título antropológico de um livro de poemas, enquanto Vou lá visitar pastores é o enunciado poético de um livro de ensaio sem notas de pé de página (vou escrever livros, Paulinha, de ensaio duro, sem notas de pé de página, prometeu em 1989, ano do Fenacult).

Há coisas que se choram muito anteriormente

Sabe-se então que a história vai mudar.

Procurou para nós a água implícita do cacto, fez cinema, escreveu livros, deixou-nos o resultado de um exaustivo labor. Não sabemos o que escolher para falar dele sem que a voz se enrugue no meio de tanta lavra, perdidos na "meia-ficção-erudito-poética-viajeira".

A quem falarei, agora, dos solstícios meu irmão? 